INTERNATIONAL JOURNAL OF RESEARCHES IN BIOSCIENCES, AGRICULTURE AND TECHNOLOGY (c) VISHWASHANTI MULTIPURPOSE SOCIETY (Global Peace Multipumose Socie ty) R. No. MH-659/13(N) www.vmsindia.org

\title{
HISTOLOGICAL AND MORPHOLOGY STUDIES OF THE MALE FRESHWATER CRAB, BARYTELPHUSA CUNICULARIS IN RELATION TO REPRODUCTION
}

\section{Bhausaheb R Ghorpade}

De partment of Zoology, Shri Anand College Pathardi, Dist. Ahmednagar (MS) 414102

bhaughorpade2007@gmail.com

\begin{abstract}
Histological and morphological changes in gonads were studied to assess the reproductive cycle of Barytelphusa cunicularis. . The number of seminiferous tubules was counted for each section and percentage was calculated for each month. Along with the se observations the seminiferous tubule diameter was noted. The observations reveale $d$ that the reproducing males of Barytelphusa cunicularis were found throughout the year. The maximum carapace le ngth was $30-56 \mathrm{~mm}$ in the male was observed in breeding season. The gonad index values of B. cunicularis showed that it is annual breeder. The testis index of crab was more in June and it was less in December. In freshwate $\mathrm{r}$ crab, s permatogenesis progressed in stages viz. primary spermatocyte, the secondary spermatocyte, the spe rmatid and spermatozoa. In Barytelphusa cunicularis the sperm is funnel shaped or conical cup shaped.

Keyw ords: Baryte lphusa, se miniferous tubules, carapace length, s pe rmatozoa
\end{abstract}

\section{Introduction}

The process of reproduction is essential for the continuation of life. The reproductive phenomenon can be examined in terms of molecular, cellular, physiological, and behavioural adaptations of individual to its environment. Mirajkar (1980) studied breeding behaviour and factors affecting reproduction in freshwater prawn. Reproduction in decapods is energy demanding physiological process. Chiou and Huang (2003) investigated seasonal changes in levels of chemical constituents in the male and female mud crab, Scylla serrata. Mantel and Dudgeon (2005) studied reproduction and sexual dimorphism of the palae monid shrimp Macrobrachium hainanense in Hong Kong streams. Herborg et al., (2006) reported mating behaviour and chemical communication in Chinese mitten crab, Eriocheir sinensis. The neuroendocrine regulation over the testicular development in mud crab, Scylla serrata was studied by Ye Haihui et al., (2006). In crustacean the carapace length is another parameter to ascertain the reproductive maturity. The morphological maturity related to carapace length in male crab, Paralomis granulosa and its reproductive phase was inferred by observing the size and carapace length (Hoggarth, 1993). The gonad index method is adapted in finding out breeding period and the relationship between the reproductive and nutritional cycle of Uca annulipes from Visakhapatnam coast (Lalitha et. al., 1996). Histological observations of gonads also support to determine reproductive cycle in crustaceans. The aim of this study was to study reproductive pattern in freshwater crab, Barytelphusa cunicularis, collected from lakes of Pathardi taluka region.

\section{Material and Methods}

The freshwater crabs Barytelphusa cunicularis were collected from Shirsatwadi and Kuttarwadi dam, near Pathardi, DistAhmednagar (M.S.) for the period of two years. The specimens from collection site were identified from Zoological Survey of India, Akurdi Pune. The crabs were collected twice a month and in each collection the to tal numbers of male was counted and were maintained separately in aerated water in glass aquarium. They were acclimatized to laboratory conditions for three days before carrying out the experiment. The water was changed thrice daily and continuous aeration was provided. The crabs were fed with earthworms or small pieces of goat meat. The percentage of immature, maturing, matured male was calculated to study the breeding behaviour. The colour of testis was observed.

For his tological studies the testes were fixed in Bouin's fluid After 24 hours of fixation the tissue were dehydrated in alcohol grade series and were paraffin embedded $\left(58-60^{\circ} \mathrm{C}\right)$. The sections were cut at 6-7 $\mu \mathrm{m}$ and stained with Harris's haematoxyline eosin.

\section{Results and Discussion \\ Breeding cycle}

The observations revealed that the reproducing males of Barytelphusa cunicularis were found throughout the year. The increase in percentage of matured male crab was related to 
reproductive season. The percentage of different reproductive phases of male crab Barytelphusa cunicularis is represented in Table. The maximum percentage of immature male crab was observed in the month January. The maximum percentage of maturing male crab was observed in the month September. The maximum percentage of matured male crab was observed in the month August. Similar reports have been cited in Barytelphusa cunicularis (Sherkhane 2006) and Barytelphusa guerini (Kengar 1998).

In crustaceans there are variations in the morophogenic appearance, location, formation and transfer of spe rmatophores. (Bendale 2006).

\section{Carapace length}

The carapace length of male crab Barytelphusa cunicularis was observed maximum in the month of August and September. The average carapace length for male ranged from $20.2 \mathrm{~mm}$ to $56.6 \mathrm{~mm}$ throughout two years.

\section{Spermatogenesis}

Histologically the testis of Barytelphusa cunicularis showed small seminiferous tubule continuous with vas deferens. The nutritive cells found in between the tubules and they were basal in position with centrally placed nucleus. The process of spermatogenesis in Barytelphusa cunicularis is completed in distinct five phases (Plate III). Fig. 1 primary spermatocytes. Fig.2 : spermatids.Fig. 3 : spermatozoa. Fig.4 : degenerating seminiferous tubules Fig.5 : Spermatophore (ST, seminiferous tubule; SP, primary spermatocytes; S, spermatid; SZ,

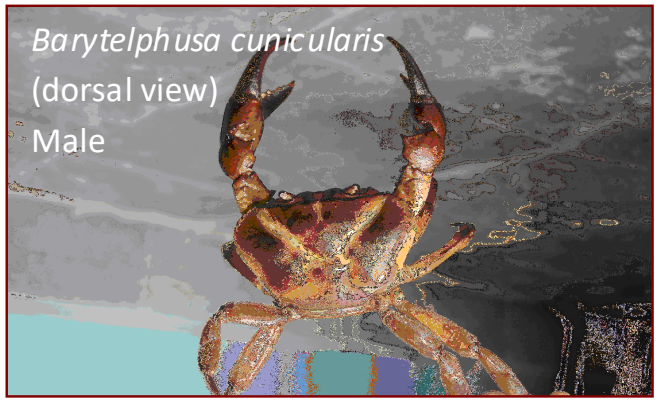

spermatozoa.SPH

Spermatophore)

\section{Spermatogonia}

Spermatogonia were differentiated from wall of the tubules. They were clearly distinguished by their large nucleus and great amount of cytoplasm. Spermato go nia, after undergoing two mitotic divisions, transformed into spermatocyte

\section{(Fig. - 1). Primary Spermatocyte}

Spermatocytes had large nuclei and great amount of cytoplasm. The most distinct change that took place during the growth of the spermatocytes was an increase in volume and size of the nucleus. The growing spermatocytes obtained the nutrients from the surrounding nutritive cells (Fig. 2)

\section{Spermatids}

Spermatids were diffe rentiated spermatocytes by recognization of the nucleus. Spermatids were round in shape and stained darkly with haematoxyline. Later they transformed into spermatozoa (Fig. 3)

\section{Spermatozoa}

When seminiferous tubule completes the spermatogenesis, they filled completely with spermatozoa. In Barytelphusa cunicularis the shape of the spermatozoa was like funnel or conical cup (Fig - 4).

\section{Spermatophore}

In Barytelphusa cunicularis the spermatophore formation took place in the vas deferens. Spermatophore was grouped together in vas deferens showed various shapes i.e. triangular oval or round. (Fig. 5)

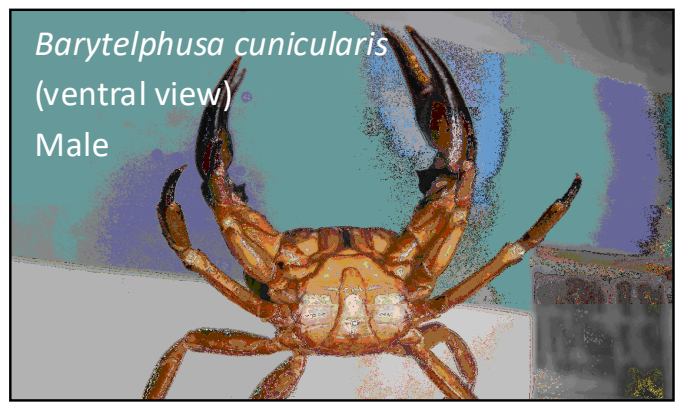



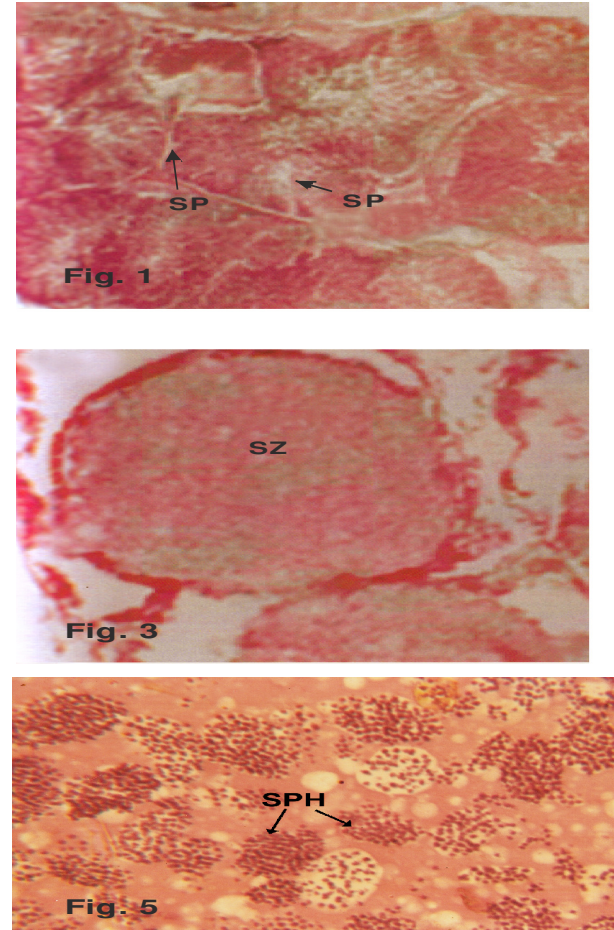

Figure -1-5 Histological section of testies of crab Barytelphusa cunicularis stained with Haematoxylin - eosin.

\section{Acknowledgements}

The author is thankful to U G C (WRO) Pune, for providing financial assistance as minor re search project (File No. 47-152/07) and to $\operatorname{Dr}$ (Mrs) Meena Patil, Professor, Dept of Zoology, Dr B A Marathwada Unive rsity Aurangabad for valuable guidance.

\section{References}

Miraikar M S (1980). Studies on the reproductive biology and neurosecretion in freshwater prawn, Macrobrachium kistnensis. Ph.D. thesis, Marathwada University, Aurangabad, M.S.

Chiou Tze-Kuei and Huang Jui- Peng (2003). Chemical constituents in abdominal muscle of cultured mud crab Scylla serrata in relation to seasonal variation and maturation. Fisheries Scie nce, 69: 597-604.

Mantel Suhmani Kaur and Dudgeon David (2005). Reproduction and sexual dimorphism of the Palaemonid shrimp Macrobrachium hainanense in Hong Kong streams. Journal of Crustacean Biology, 25(3): 450-459.

Herborg Leif-Matthias, Matthew G Yentley, Anthony S Clare, Kim S Last (2006). Mating behaviour and chemical communication in the invasive Chinese mitten crab, Eriocheir sinensis. Journal of Experimental Marine Biology and Ecology, 329: 1-10.
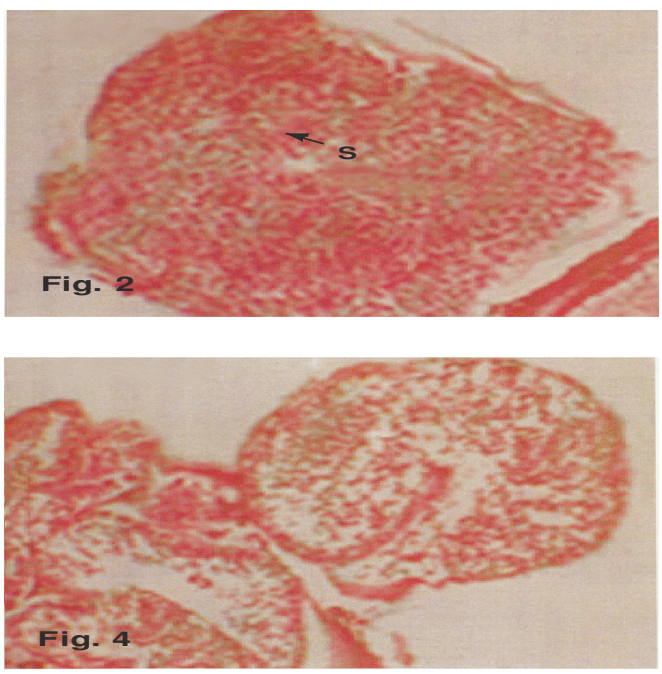

Ye Haihui, Huang Huiyang, Li Shaojing Wang Guizhong, Li Qifu (2006). In vitro study of neuroendocrine regulation over the testicular development in mud crabs Scylla serrata. Chinese Journal of Oceanography and Limnology vol. 24 No.2: 142-146.

Hoggarth, D D (1993). The life history of the lithodid crab, Paralomis granulosa, in the Falkland Islands the exploration of the sea) Journal of marine science, 50 (4): 405-424.

Lalitha M K, Shyamasundari; K Hanumantha Rao and G Raieswari (1996). Annual reproductive cycle of the fiddler crab Uca annulipes latreille (Decapoda:Crustacea) in relation to nutrition. Advances in Biosciences (1996), vol. 15(11): 1-16.

Sherkhane Usha, (2006). Neuronal organization and role of endocrine centres in some physiological aspects of freshwater crab, Barytelphusa cunicularis. Ph.D. Thesis Marathwada University, Aurangabad.

Kengar S B (1998). Ecophysiological studies in freshwater crab, Barytelphusa guerini. Ph.D. thesis, Marathwada University, Aurangabad, M. S.

Bendale B T (2006) A study on reproductive biology of crustaceans from Dahanu region. Ph. D. thesis, Marathwada University, Aurangabad, M.S. 